\title{
THE ROLE OF SERVICES IN THE POLISH FOREIGN TRADE IN 2010-2017
}

\author{
JOLANTA ZIEZIULA \\ University of Szczecin, Faculty of Management and Economics of Services, POLAND \\ e-mail: jolanta.zieziula@wzieu.pl
}

\begin{tabular}{l|l} 
RECEIVED & 6 November 2018 \\
ACCEPTED & 3 December 2018 \\
JEL & \\
CLASSIFICATION & F14, F40, 019
\end{tabular}

KEYWORDS services, foreign, trade

ABSTRACT The article focuses on the Polish foreign trade in services. It describes export, import and trade balance with the main goal to identify trends and structural changes. The article covers the period of 2010-2017. It has been chiefly based on the literature and information derived from reports of the National Bank of Poland and the Polish Central Statistical Office (CSO). The research is based on analysis of available data, as well as description combined with deductive reasoning. The presentation of findings has been supplemented by tables and figures. Research findings confirm that the value of services in the Polish foreign trade has increased. This applies to export, import, and trade balance. In the period concerned, we also witness major changes in the structure of main types of services, and this can be seen in export and import of services, including the largest drop that the Polish foreign trade has been recorded in foreign trips. The largest increase in the export of services, however, has occurred in inward processing, whereas in the import of services in the category of transport. The study has confirmed that the role of services in the Polish foreign trade is growing.

\section{Introduction}

Benefits that countries derive from foreign trade determine increasingly rapid growth of the economic activity. Although today, goods prevail in the structure of international trade, the role of services has been notably growing. This is confirmed by fiures pertaining to the international trade in services, as well as its growing contribution to the GDP. Such trends can also be seen in the Polish foreign trade. 
The publication examines practical issues based on Polish services trade statistics. Therefore, the analysis focuses on the foreign trade in services in particular. The above has been complemented by the assessment of the trade in the overall context of the Polish economic growth.

\section{Litergture review}

Although literature on the foreign trade is abundant, there are rather few publications concentrating on services. The reason is that it is difficult to define the term of 'service', since there are various approaches and classifications of services (Kisiel-Łowczyc, 1994, pp. 80-90), and it is difficult to collect relevant statistics. The first Polish publication providing comprehensive overview of objectives, conditions and conseqeunces of the liberalisation of international trade in services was published in the end of the first decade of the 21st c. (Wróbel, 2009).

The international trade in services is fairly new. Until the mid 20th c., services were considered to include activities not suitable for international trade without much potential for development (Klima 2014, p. 230). Consequently, interntational trade in services is the least developed part of the international trade theory. It should be emphasised that no universal and exhaustive theory has ever been developed regarding intenational trade in services. Thererefore, there is no universal and generally acceptable model in this area (see Misala, 2005, pp. 145-150). It has been known, however, that foreign trade in general, including the trade in services, has positive influence on the development of economies (Krugman, Obsfeld, 2007; Jones; Kierzkowski, 2018, pp. 233-253; Malkowska, 2017, pp. 57-75).

\section{Method}

Although the article touches upon the issue of foregin trade, it concentrates on the trade in services. The analysis mainly covers such categories as export of services, import of services and trade balance. As regards the territory covered, the study focuses on the area of Poland.

The goal of the study is to identify trends in the Polish foreign trade in services and present structural changes. For the purpose of the analysis, the following hypothesis has been adopted: The rapid growth of the Polish foreign trade in services is accompanied by profound changes in the structure of those services.

The analysis covers a period of 2010-2017. The scope, however, is determined by the availability of homegenous statistical data. The paper mainly uses literature and information taken from reports by the National Bank of Poland and the Central Statistical Office (CSO). The methodology is based on analysing available data and a descriptive method combined with elements of deductive reasoning. Findings are presented in the article and supplemented by tables and figures.

\section{Results}

\section{Polish foreign trade in services in 2010-2017}

The value of services provided by Poland on foreign markets increased from PLN 106.9 bn to PLN 220.7 bn between 2010 and 2017. It means an imposing increase, since the value more than doubled. While analysing year to year figures, we can see a steady growth. This applies to the export of services, their import, and the trade balance (see Figure 1). In the period concerned, the value of services purchased in the Polish foreign trade grew by $54 \%$. 
In 2010, the Polish import of services reached PLN 93.7 bn, and in 2017 it was already PLN 144.3 bn. Thus, the export of services grew much faster than the import.

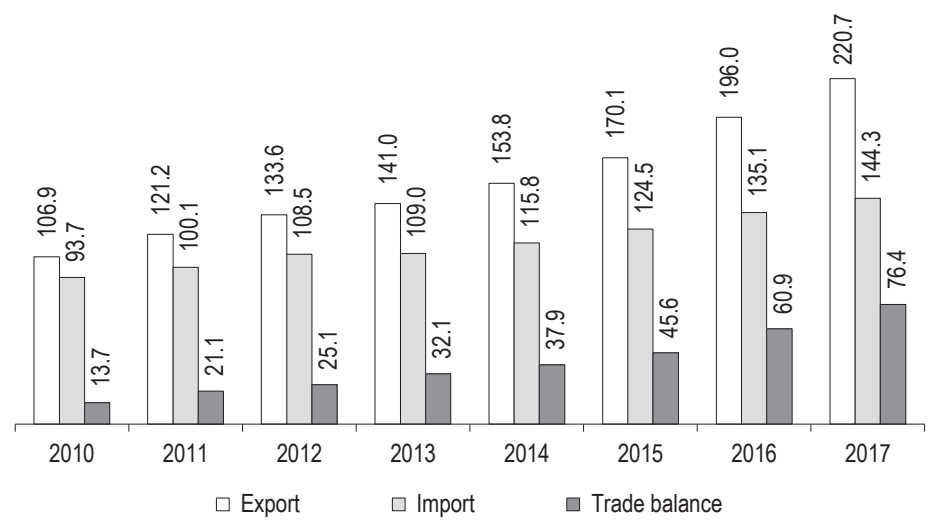

Figure 1. Export, import and balance of international trade in services for Poland in 2010-2017 (PLN bn)

Source: author's analysis based on National Bank of Poland (NBP, 2014); National Bank of Poland (NBP, 2017).

In 2010-2017, the trade balance in services was positive and it moved from PLN 13.7 bn to PLN 76.4 bn, which translated into a six-fold increase. The 2017 surplus was the largest in the Polish history. Transport services dominated in the development of foreign trade. The considerably long period of analysis covering eight years indicates that Poland had a robust service export surplus. The increase in the surplus resulted mainly from much faster growth of income over spending. It is worth emphasising that the trade in services was more beneficial comparing with the trade in goods. Regarding the latter, in 2010-2014, the Poland's trade balance was negative, and the surplus was recorded in 2015-2016 only.

In the period concerned, we witnessed major changes regarding primary components of services, which played a decisive role in terms of the value of the Polish export and import of services. In 2010, the largest export value was in the group of other services, which reached PLN 43.6 bn. In the group concerned, other business services accounted for as much as $66.8 \%$. This component includes mainly knoweldge-driven services and services related to innovation, which have potential of generating the largest profit (Noland, Park, Estrada, 2013, p. 3). Such services as telecommunication, IT and information and other business services (including R\&D, business consulting, marketing, legal, accounting, and management), as well as use of intellectual property, generated export income of PLN 35.9 bn and PLN 75.1 bn, respectively in 2010 and 2017. From the point of view of the Poland's econmic growth, the changes were very positive.

Other services generating major income for the Polish economy included foreign trips (PLN 29 bn), and transport (PLN 26.8 bn). In 2010, repairs were at the very end of the Polish service export scale (PLN 2.1 bn), which accounted for only $2 \%$ of export revenue. In 2017, other services continued playing their major role (PLN 90.6 bn). However, in comparison with 2010, transport started to be ranked second (see Table 1). 
Table. 1. Polish foreign trade by main service components in 2010 and 2017 (PLN bn)

\begin{tabular}{lcccc}
\hline \multirow{2}{*}{ Service } & \multicolumn{2}{c}{2010} & \multicolumn{3}{c}{2017} \\
\cline { 2 - 5 } & export & import & export & import \\
\hline Inward processing & 5.3 & 0.4 & 15.9 & 1.4 \\
Repairs & 2.1 & 0.6 & 6.6 & 3.6 \\
Transport & 26.8 & 18.9 & 59.6 & 33.0 \\
Foreign trips & 29.0 & 26.0 & 48.0 & 33.3 \\
Other services & 43.6 & 47.8 & 90.6 & 73.0 \\
\hline
\end{tabular}

Source: author's analysis based on NBP (2014) and NBP (2017).

As regards the Polish import of services, other services reached the highest value both in 2010 (PLN 47.8 bn) and 2017 (PLN 73 bn). Inward processing generated the smallest value, since its import was PLN 0.4 bn in the base year and PLN 1.4 bn in the target year.

In the period concerned, the Polish foreign trade witnessed an increase in all main categories of services. The situation changed rapidly. The largest increase in export was generated by repairs (314\%), inward processing (300\%), transport (222\%), other services (208\%) and foreign trips (165\%), whereas in import, major increase occurred in repairs $(600 \%)$, and the smallest in transport $(75 \%)$. It should be emphasised that the rate of increase in particular components, with the exception of repairs, was higher than in the export of services, This development was positive from the point of view of the Poland's economic growth (see Malkowska, Malkowski, 2018, pp. 306-312).

The period of 2010-2017 brought major changes in the structure of service exports. In comparison with 2010, in 2017, only one component reduced its share in the overall structure. It was the category of foreign trips which dropped from 27.2 to $21.7 \%$. Other categories increased, with the largest increase in inward processing (from 5 to $7.2 \%$ ), then transport (from 25.1 to $27 \%$ ), repairs (from 2 to $3 \%$ ) and other services (from 40.8 to $41.1 \%$ ). As regards import of services, two categories decreased, i.e. foreign trips (from 27.7 to $23.1 \%$ ) and other services (from 51 to $50.6 \%$ ), whereas transport increased its share in import of services (from 20.2 to $22.9 \%$ ), and the same applied to repairs (from 0.6 to $1.9 \%$ ) and inward processing (from 0.4 to $1 \%$ ).

\section{The role of services in the Polish foreign trade}

According to the study, the changes of the value of foreign trade in services have pointed to a growing trend. It is important, however, to assess the influence of that increase on the economic growth. The first indicator for assessing the importance of export for the Polish economy is the ratio of export to the gross domestic product (GDP). The indicator is known as the trade-to-GDP ratio. The higher the ratio, the better for the economy. The ratio points to the economic potential of a country and its competitiveness for partners from other countries.

In the period concerned, the ratio for service export steadily increased from $7.4 \%$ in 2010 , to $11.1 \%$ in 2017 (see Figure 2). Thus, the value increased by 3.7 percentage points.

In 2010, the share of service import in the Polish GDP was 6.5\%, whereas in 2017 it was $7.3 \%$, which is an increase by 0.8 percentage points (see Figure 3 ). The value of the indicator is relatively low, which is positive from the point of view of the Polish economy. The lower the value, the less an economy depends on imports. We should remember, however, that the import can improve the structure of services in the economy. 


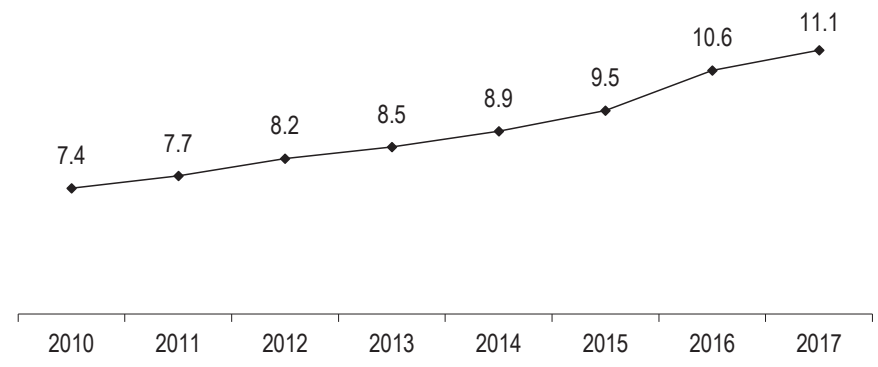

Figure 2. Service export to Poland's GDP (\%)

Source: author's analysis based on National Bank of Poland (NBP) 2014, NBP (2017); Local Databank of Central Statistical Office (BDL GUS 2010-2017).

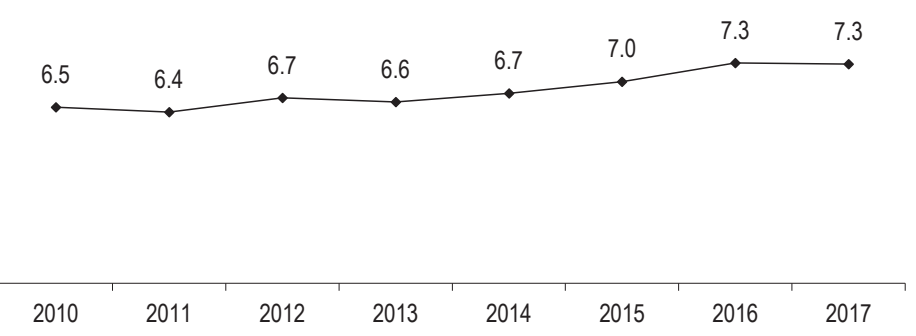

Figure 3. Service import to Poland's GDP (\%)

Source: author's analysis based on NBP (2014); NBP (2017); BDL GUS (2010-2017).

The growing importance of the trade in services for the Polish economy can be seen in the ratio between the export and import of services per capita. In 2010, the export of services per capita was PLN 2.8 thou., whereas in 2017 it was PLN 5.8 thou. This translates into an imposing increase by $207 \%$.

The import of services per capita was PLN 2.5 thou. in the base year, whereas PLN 3.8 thou. in the target year. Thus, the ratio inceased by $152 \%$. This can be explained by larger purchase of services on foreign markets, the increase in the prices of services, and growing openness of the economy to foreign trade. Similarly to foreign trade in services in general, in the period concerned, the growth of service exports per capita was larger than in the case of service imports.

The development of the Polish foreign trade results from the increase in the number of companies involved in export and import. The total number of export companies in Poland increased from 31,434 in 2010 (Marshal's Office of Małopolskie Province, 2011) to 41,273 in 2015 (Poniewski, Skóra, 2018, p. 14), which translates into an increase by $31.3 \%$. Incomplete 2017 figures also indicate the same growing trend. For instance, according to the $\mathrm{CSO}$, the number of export companies employing more than 9 people increased and at the end of 2017 to reach 17.7 thou (PKO BP, 2018). 
In 2010, in Poland, we had over 23 thou. companies with foreign interest, of which as many as 9,475 were involved in export and 10,610 in import. This means that $41.1 \%$ of those companies exported services, whereas $46.0 \%$ imported them (CSO, 2011).

In 2016, in Poland, we had 24.8 thou. companies with foreign interest, of which as many as 11,239 companies were involved in export and 11,938 in import. Therefore, $45.4 \%$ of those companies exported services and $48.2 \%$ imported services (CSO, 2017). As we can see, in 2010-2016, the number of companies with foreign interest increased, and the same applies to the number of companies involved in foreign trade in services.

In the period concerned, the value of services exported by companies with foreign interest doubled, from PLN 39.4 bn in 2010 to PLN 78.2 bn in 2016. In the same period, import of services grew from PLN 28.2 bn to PLN 50.4 bn, which translates into an increase of $78.7 \%$.

The service trade surplus could be observed in transactions by companies with foreign interest and domestic companies alike. In 2010 and 2016 the surplus was PLN 17.8 bn and PLN 35.7 bn respectively. It means that transactions by companies with foreign interest accounted for only $33.3 \%$. The positive balance, to a large extent (66.7\%), was generated by domestic companies (NBP, 2016).

\section{Conclusions}

In 2010-2017, we witnessed major changes in the Polish foreign trade in services. The study highlighed a positive growing trend, especially regarding the export of services in general, where the growth rate was higher than in the import of services. Since 2010 , services accounted for a positive trade balance, which steadily increased.

The analysis of foreign trade in services has also shown a major change in its structure. We observe a gradual shift from simple to more sophisticated services. Over double increase in the export of knowledge-driven services and services related to innovation is a positive sign from the point of view of the economic growth.

We witness growing openness of the Polish eocnomy to internatioal trade in services. Moreovoer, the role of services strengthenes due to more efficient use of human resources. Additionally, a growing number of companies, including those with foreign interest, are involved in foreign trade. It should be emphasised that domestic companies contributed more to the surplus in the service trade balance. This means that those businesses have become more competitive comparing to companies with foreign interest. Therefore, we may assume that to a large extent Poland's trade in services determined economic development of the country.

Rapid changes in the foreign trade in services and its growing significance for the economic growth require further research. We should examine whether the positive development trend continues. Relevant institutions should collect precise data about foreign trade in services and provide such information, also in its not aggregated form to support indepth analyses. Those analyses can help to spot any threats and apply countermeasures by political and economic decision makers at national, regional and local levels.

\section{References}

GUS (2010-2017). Bank Danych Lokalnych. Retrieved from: https://bdl.stat.gov.pl/BDL/start (12.10.2018).

GUS (2011). Działalność gospodarcza podmiotów z kapitałem zagranicznym w roku 2010. Warszawa.

GUS (2017). Działalność gospodarcza podmiotów z kapitałem zagranicznym w roku 2016. Warszawa.

Jones, R.W., Kierzkowski, H. (2018). The role of services in production and international trade: A theoretical framework. World Scientific Book Chapters, International Trade Theory and Competitive Models Features, Values, and Criticisms, chapter 14. World Scientific Publishing Co. Pte. Ltd. 
Kisiel-Łowczyc, A.B. (1994). Współczesna gospodarka światowa. Gdańsk: Wydawnictwo Uniwersytetu Gdańskiego.

Klima, S. (2014). Kierunki eksportu polskich usług na rynki pozaunijne w warunkach liberalizacji handlu światowego. In: S. Wydymus. B., Pera (eds.), Perspektywy rozwoju polskiego eksport do krajów pozaunijnych. Warszawa: Difin.

Krugman, P.R., Obsfeld M. (2007). Ekonomia międzynarodowa, Teoria and polityka. Część I. Warszawa: Wydawnictwo Naukowe PWN.

Malkowska, A. (2017). Eksport jako czynnik rozwoju województw zachodniego pogranicza Polski. Przedsiębiorczość i Zarządzanie, 18 (2, cz. III), 57-75.

Malkowska, A. Malkowski, A. (2018), Assessment of the Development of a Border Area using Poland's Eastern Borderland as an example. Proceedings of the 2018 International Conference Economic Science For Rural Development, No. 48, Jelgava, 9-11 May, 306-312.

Marshal's Office of Małopolskie Province (2012). Handel zagraniczny w Polsce and Małopolsce w roku 2011. Kraków.

Misala, J. (2005). Wymiana międzynarodowa a gospodarka światowa. Teoria i mechanizmy funkcjonowania. Warszawa: Oficyna Wydawnicza SGH.

NBP (2014). Międzynarodowy handel usługami. Retrieved from: https://www.nbp.pl/home.aspx?f=/statystyka/mhu.html (10.10.2018).

NBP (2017). Międzynarodowy handel usługami. Retrieved from: https://www.nbp.pl/home.aspx?f=/statystyka/mhu.html (10.10.2018).

Noland, M., Park, D., Estrada, G.B. (2013). Can a Growing Services Sector Renew Asia's Economic Growth? Asia Pacific Issues, 109, $1-8$.

PKO BP (2018). Polska - podmioty eksportujące w 2017 roku. Retrieved from: https://www.pkobp.pl/aktualnosci/aktualnosci-eksportera/ polska-podmioty-exportjace-w-2017-roku (12.10.2018).

Poniewski, R., Skóra, M. (2018). Handel zagraniczny w Polsce i Małopolsce w roku 2016. Kraków: Marshal's Office of Małopolskie Province.

Wróbel, A. (2009). Międzynarodowa wymiana usług. Warszawa: Scholar.

Citte this article aS: Zieziula, J. (2018). The role of services in the Polish foreign trade in 2010-2017. European Journal of Service Management, 4 (28/1), 351-357. DOI: 10.18276/ejsm.2018.28/1-44. 